\title{
Evapotranspiration Studies for Protective Barriers: Experimental Plans
}

S. O. Link

W. J. Waugh

November 1989

Prepared for the U.S. Department of Energy under Contract DE-AC06-76RLO 1830

Pacific Northwest Laboratory

Operated for the U.S. Department of Energy by Battelle Memorial Institute 


\title{
DISCLAIMER
}

This program was prepared as an account of work sponsored by an agency of the United States Government. Neither the United States Government nor any agency thereof, nor Battelle Memorial Institute, nor any or their employees, makes any warranty, expressed or implied, or assumes any legal liability or responsibility for the accuracy, completeness, or usefulness of any information, apparatus, product, or process disclosed, or represents that its use would not infringe privately owned rights. Reference herein to any specific commercial produc, process, or service by trade name, trademark, manufacturer, or otherwise, does not necessarily constitute or imply its endorsement, recommendation, or favoring by the United States Government of any agency thereof, or Battelle Memorial Institute. The views and opinions of authors expressed herein do not necessarily state or reflect those of the United States Government or any agency thereof.

\author{
PACIFIC NORTHWEST LABORATORY \\ operated by \\ BATTELLE MEMORIAL INSTITUTE \\ for the \\ UNITED STATES DEPARTMENT OF ENERGY \\ under Contract DE-AC06-76RLO 1830
}

Printed in the United States of America

Available to DOE and DOE contractors from the

Office of Scientific and Technical Information, P.O. Box 62, Oak Ridge, TN 37831;

prices available from (615) 576-8401. FTS 626-8401.

Available to the public from the National Technical information Service,

U.S. Department of Commerce, 5285 Port Royal Rd., Springfield, VA 22161.

NTIS Price Codes, Microfiche A01

\begin{tabular}{|c|c|}
\hline \multicolumn{2}{|c|}{ Printed Copy } \\
\hline Pages & $\begin{array}{l}\text { Price } \\
\text { Codes }\end{array}$ \\
\hline $001-025$ & $\mathrm{A02}$ \\
\hline $026-050$ & $\mathrm{~A} 03$ \\
\hline $051-075$ & $\mathrm{~A} 04$ \\
\hline $076-100$ & A05 \\
\hline $101-125$ & $A 06$ \\
\hline $126-150$ & $\mathrm{~A} 07$ \\
\hline$\uparrow 51-175$ & $\mathrm{~A} 08$ \\
\hline $176-200$ & A09 \\
\hline 201.225 & A10 \\
\hline $226-250$ & A11 \\
\hline $251-275$ & $\mathrm{~A} 12$ \\
\hline $276-300$ & A13 \\
\hline
\end{tabular}


PNL6899

UC-702

\title{
EVAPOTRANSPIRATION STUDIES FOR PROTECTIVE BARRIERS: \\ EXPERIMENTAL PLANS
}

\author{
S. O. Link \\ W. J. Waugh
}

November 1989

Prepared for

the U. S. Department of Energy

under Contract DE-AC06-76RLO 1830

Pacific Northwest Laboratory Richland, Washington 99352 


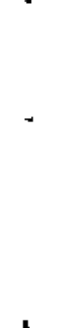

' • 


\section{EXECUTIVE SUMMARY}

This document describes a general theory and experimental plans for predicting evapotranspiration in support of the Protective Barrier Program. Evapotranspiration is the combined loss of water from plants and soil surfaces to the atmosphere.

The objective of the evapotranspiration study is to predict potential water drainage into buried waste over periods of up to 10,000 years with the barrier in place. To accomplish this objective, instruments will be developed to measure and collect evapotranspiration and transpiration data. The data will then be used to parameterize evapotranspiration models. The experiments will be conducted in conjunction with studies at the Field Lysimeter Test Facility, the Small-Tube Lysimeter Facility, and McGee Ranch, and with other tasks in the Protective Barrier Program. 


\section{ACKNOWLEDGMENTS}

The work described in this experimental plan was funded by the U.S. Department of Energy. Discussions with Peter Beedlow, Mike Fayer, Glendon Gee, Randy Kirkham, and Bill Rickard of Pacific Northwest Laboratory are gratefully acknowledged. 

CONTENTS

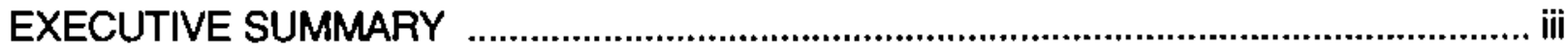

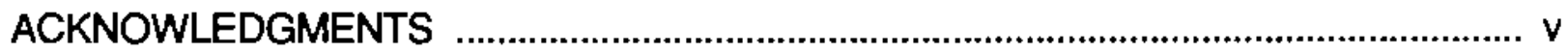

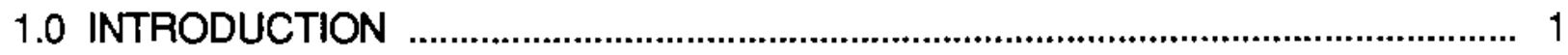

2.0 BACKGROUND .............................................................................................

2.1 PREDICTING EVAPOTRANSPIRATION .................................................... 3

2.1.1 Holism Versus Reductionism .......................................................... 3

2.1.2 Mechanistic and Empirical Models ................................................. 4

2.2 FACTORS CONTROLLING EVAPOTRANSPIRATION …................................ 5

2.2.1 Stomatal Models and Factors Controlling Stomatal Conductance............................................................................................ 6

2.2.2 Model of Kuppers and Schulze .................................................. 8

2.2.3 Model of Avissar et al. .................................................................... 12

2.3 GAS EXCHANGE WHOLE PLANT SYSTEM MODELS............................... 14

3.0 GAS EXCHANGE EXPERIMENTAL PLANS .................................................. 17

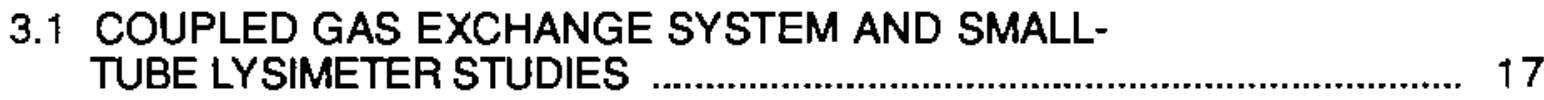

3.1.1 Phase 1: System Construction and Testing........................................ 18

3.1.2 Phase II: Treatment Effects ….......................................................... 20

3.1.3 Phase III: Modeling ............................................................................... 22

3.2 MCGEE RANCH PLANT WATER RELATIONS ............................................ 23

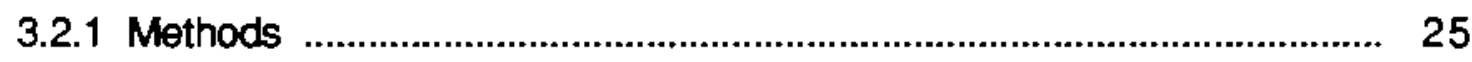


4.0 RELATIONSHIP TO OTHER TASKS IN THE PROTECTIVE BARRIER DEVELOPMENT PROGRAM

4.1 ANIMAL BURROW CHARACTERISTICS …….......................................... 29

4.2 BURROWING EFFECTS ON WATER INFILTRATION ............................... 29

4.3 PLANT INTRUSION TESTS ................................................................. 29

4.4 PREDICTION AND INTEGRATION ....................................................... 30

4.5 PLANT TRANSPIRATION DATA COLLECTION AND MODELING ........... 30

4.6 GRAVEL MULCH STUDIES................................................................... 30

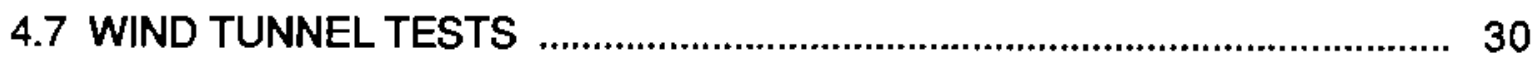

4.8 WATER EROSION STUDIES …............................................................... 31

4.9 DEPOSITION OF WIND-BLOWN PARTICLES STUDIES ......................... 31

4.10 APPLICATIONS OF COMPUTER MODELS ......................................... 31

4.11 MODEL VALIDATION ........................................................................ 31

4.12 ARMORED-SURFACE ANALOG FIELD STUDIES ............................... 31

4.13 MICRORELIEF EFFECTS …............................................................. 32

4.14 PLANT COMMUNITY DYNAMICS ……….......................................... 32

4.15 LOCAL CLIMATE AND VEGETATION CHANGES ............................... 32

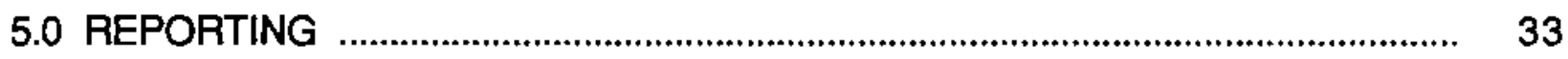

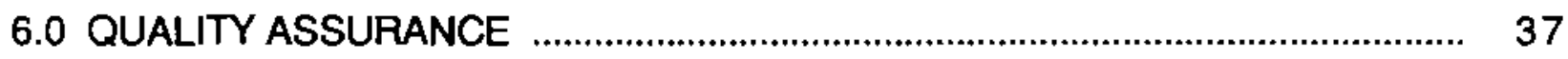

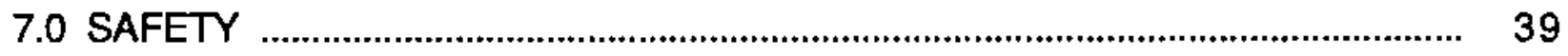

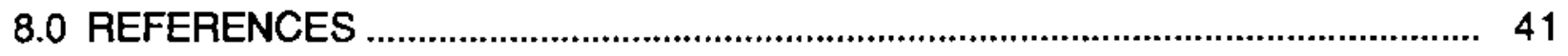




\section{EIGURE}

2.1 Diagram of the PRECO Model.......................................................................... 15

\section{IABLES}

3.1 Treatment Structure for the Small-Tube Lysimeter Experiment ........................ 21

5.1 Plant Gas Exchange Experiment Costs............................................................ 34

5.2 McGee Ranch Ecophysiology Experiment Costs............................................... 35

6.1 Quality Controlled Instruments: Calibration and Operation.............................. 37 



\subsection{INTRODUCTION}

Protective barriers have been identified as fundamental components for providing long-term isolation of Hanford defense wastes for near-surface disposal locations (DOE 1987). A program is being conducted that addresses barrier performance standards, technology development, and design (Wing 1988). The program objective is to design a barrier that will be functional for an extended design life of up to 10,000 years. The barrier must prevent the migration of waste products to the land surface where they could become distributed in the environment and must also control the downward migration of contaminants to groundwater. Thus, intrusion by man or the natural biota, erosion or loss of the barrier, and infiltration of surface water are major design considerations.

A series of tasks has been initiated by Pacific Northwest Laboratory (PNL) through Westinghouse Hanford Company (Westinghouse Hanford) to address protective barrier and warning marker system development (Wing 1988).

Evapotranspiration has been identified as factor that must be considered during barrier development. The experimental plans in this document have been written to investigate evapotranspiration, with the objective of minimizing the amount of water drainage into the waste. To assess the performance of protective barriers, it is necessary to predict the evapotranspiration rate that may occur over the life of the barrier. For example, water could enter the barner as precipitation and leave by evapotranspiration, and any water not lost by evapotranspiration potentially could enter the waste by drainage.

The purposes of the investigations discussed in this plan are to:

- develop and test instruments to measure evapotranspiration, specifically an environmentally controlled whole plant gas exchange system

- measure evapotranspiration data at the whole plant level on small-tube lysimeters, using the PNL-developed instruments

- measure transpiration data on shrubs at the McGee Ranch site.

These data will be used to parameterize the plant component of the UNSAT-H code (Fayer et al. 1986), which is being used to predict evapotranspiration. However, because the plant component of the model is based on only 2 months of cheatgrass (Bromus tectorum) growth, it is limited in 
its ability to predict long-term drainage. Simulations using a revised version of UNSAT-H will allow us to judge the effectiveness of proposed barrier configurations.

Section 2.0 of this plan develops the evapotranspiration theory. Section 3.0 details gas exchange experiments to be conducted on small-tube lysimeters at the Small-Tube Lysimeter Test Facility and transpiration experiments to be conducted at McGee Ranch. The relationship between evapotranspiration studies and other relevant tasks in the Protective Barrier Development Program are described in Section 4.0. Section 5.0 outlines reporting requirements. Quality assurance information is provided in Section 6.0, and safety procedures are described in Section 7.0 


\subsection{BACKGROUND}

This section summarizes different approaches for predicting evapotranspiration, describes the factors controlling evapotranspiration, and discusses recent gas exchange models that may be used to predict plant water extraction from barriers.

\subsection{PREDICTING EVAPOTRANSPIRATION}

Evapotranspiration is the combined loss of water from plants and soil surfaces to the atmosphere, while evaporation is generally considered water lost from the soillitter surface, and transpiration is water lost from plants. Evapotranspiration is a major source of water loss from the ecosystem, with plants accounting for most of the loss in crop (Hanks and Ashcroft 1980; Kramer 1983) and arid systems (Campbell and Harris 1977). Transpiration is the most difficult of the three processes to predict because of the many factors that influence plant transpiration.

A model to predict evapotranspiration must account for a wide range of climatic and plant community possibilities. Given adequate computer resources, the model should be able to predict evapotranspiration on a time step small enough (e.g., 30 $\mathrm{min}$ ) to incorporate significant diurnal variation in plant activity. Diurnal prediction can be integrated numerically to yield daily evapotranspiration, and daily values can then be integrated to provide seasonal values. These values can be integrated to any point in the future relevant to drainage processes. The model must also predict evapotranspiration for conceivable climate and ecosystem changes, which can be accomplished by changing parameters and environmental input values as the simulation progresses. The unsaturated flow moisture code (UNSAT-H), which is being developed to predict water drainage through barners given predictions of future environmental states, is currently limited by its uncertainty in simulating the water extraction behavior of plants.

\subsubsection{Holism Versus Reductionism}

Evapotranspiration can be measured either holistically at the community level, or as the sum of soil evaporation and plant transpiration. Each approach provides only part of the answer. Community-level data of the holistic approach integrate water loss by soil and plants, but do not lend well to parameterization of mechanistic 
relationships. Separate soil and plant data of the reductionism approach allow for parameterization of mechanistic relationships, but may not account for communitylevel synergy.

This basic conflict between holistic and reductionism approaches to quantifying transpiration was reviewed by Jarvis and McNaughton (1986). They attribute the difficulty in scaling up from individual plant measurements to community-wide transpiration to how the information is gathered. Histonically, meteorologists have concluded that solar energy controls transpiration, not the modulation of stomates by plants. Physiologists have contended that transpiration is controlled entirely by stomatal modulation. Jarvis and McNaughton (1986) theorize that the proportions of transpiration controlled by solar energy and by stomates can be quantified based on boundary-layer thickness. Their basic conclusion is that the smaller the leaf, the greater the boundary layer conductance and, consequently, the greater stomatal control of transpiration. Characteristic of arid land plants, the species expected to inhabit barriers have small leaves. This supports gas exchange work at the plant level using the reductionism approach.

Because UNSAT-H will require mechanistic descriptions of evapotranspiration, soil and plant model development may need to be done separately. Model validation, however, should include correlations of model predictions with holistic measurements. To accomplish this, soil and plant components can be measured separately with a combination of lysimetry and gas exchange techniques. Estimates of community-level evapotranspiration can be made by water balance, energy budget (Bowen ratio and Eddy correlation), and lysimetry coupled with long- and short-range multispectral remote sensing. These methods will provide data representative of integrated activity of soil and plant and have been reviewed in Advances in.Eyapotranspiration (ASAE 1985).

\subsubsection{Mechanistic and Empirical Models}

The problem in writing differential equations describing the separate responses of plants and soil to the environment is determining the functional form and parameter values for the equations. Although mechanistic formulations best predict the future, their parameterization is based on empirical data. A mechanistic model breaks system processes into individual physical and chemical components and then attempts to 
explain the behavior of the whole system from the behavior of the individual system components and their interactions (Thornley 1976).

Currently, it is not possible to formulate mechanistic ecosystem-level models by this strict definition. Instead, the best mechanistic model is usually combined with empirical information. Most functional relationships for plants cannot be expressed as physical laws at the fundamental component level. In practice, component levels are chosen to conform to the capabilities of current technology. Most model components will combine underlying physical and chemical processes; thus, functional relationships are only empirically known, and parameter values for them are not constants as in a fundamental physical law. For this reason, parameters for such equations must be determined by controlled expenimentation. Functional relationships for transpiration are known for some plants, but for uninvestigated species even the form of these relationships must be determined by controlled experimentation.

\subsection{EACTORS CONTROLLING EVAPOTRANSPIRATION}

Evaporation from the soil depends on soil hydraulic properties, soil water content, surface litter, the poikilohydric plant cover, vascular plant shading, solar radiation, temperature, atmospheric vapor pressure deficit, wind speed, and animal activity. Transpiration is controlled by the supply of water to roots, plant-liquid water conductance, stomatal conductance, and leaf area. If a plant acquires adequate water by root exploration, it will transpire at rates controlled by plant-liquid water conductance, stomatal conductance, and leaf area. As the supply of water is reduced, transpiration will be reduced.

Plant-liquid water conductance is mainly a function of root temperature, the depth of usable water, and species. Root growth is controlled mainly by soil temperature, nutrient status, soil water content, carbon gain, and genetically determined species-specific phenology. Stomatal conductance is mainly a function of internal $\mathrm{CO}_{2}$ concentration, light, temperature, vapor pressure deficit, leaf water potential, leaf age, wind speed, nutrient status, acclimation to current environmental conditions, and species effects. Leaf area is mainly a function of carbon gain, nutrient status, water stress, and genetically determined species-specific phenology. Carbon gain is a function of several of the above factors and is closely related to the water 
status of the plant. Because of water stress, stomatal closure necessarily restricts the supply of $\mathrm{CO}_{2}$ to the plant.

\subsubsection{Stomatal Models and Factors Controlling Stomatal Conductance}

This section reviews the abiotic and biotic factors controlling stomatal conductance and discusses two multivariate models. Stomatal conductance is the primary determinant of plant water status in the water column from the soil through the roots to leaves and into the atmosphere (Kramer 1983). Most models of stomatal conductance consider, at most, only a few of the environmental or biological factors that control stomatal aperature. Most models are specific for the conditions of the experiment, such as time of year or growing conditions, and are not easily extended to other conditions. Although models have not been found that take into account all important factors controlling stomatal conductance, a few multivanate models exist, which are described below.

\subsubsection{Abiotic and Biotic Factors Centrolling Stomatal Conductance}

The most important environmental factors that control stomatal conductance are light intensity, light quality, $\mathrm{CO}_{2}$ concentration, temperature, humidity, wind speed, soil nutrient status, and leaf water potential.

The response of stomatal conductance to the intensity of white light is a saturation type with conductance increasing rapidly with initial increments of light and leveling off at higher light intensities. The exact form of the relationship depends on the species and other factors that control conductance (Hsiao 1975). Stomatal opening responses are most responsive to light in the blue portion of the spectrum with a peak of action extending from 420 to $460 \mathrm{~nm}$ and no action $>560 \mathrm{~nm}$. Stomata will respond to this light at low intensities (Raschke 1975). Light in the green portion of the spectrum elicits an opening response only at high intensities (Farquhar and Sharkey 1982).

Stomata tend to operate to maintain internal $\mathrm{CO}_{2}$ constant in some species (Raschke 1975), opening as internal concentrations drop, and closing as concentrations increase (Sheriff 1979). This regulatory mechanism controlling assimilation of $\mathrm{CO}_{2}$ also controls transpiration. Thus, photosynthetic models that 
predict internal concentrations of $\mathrm{CO}_{2}$ are required to properly simulate transpiration (Hall 1982). Stomata also close at high extemal $\mathrm{CO}_{2}$ concentrations (Hsiao 1975), which should be considered because predictions for increasing global levels of atmospheric $\mathrm{CO}_{2}$.

The most common relationship between temperature and stomatal conductance is one with increasing conductance to a broad temperature, then optimum declining with increasing temperature (Hsiao 1975; Avissar et al. 1985). Other relationships observed include decreasing, increasing, or relationships that are not related to temperature (Sheriff 1979).

A direct relationship between the vapor pressure gradient and stomatal conductance was conclusively demonstrated by Lange et al. (1971) and termed a feedforward stomatal response (Cowan 1977). The general form of the relationship is a linearly (Warnit, Landsberg, and Thorpe 1980), exponentially (Roessier and Monson 1985), or threshold-type (Avissar et al. 1985) decreasing function with increasing vapor pressure deficit, depending on species and conditions.

Stomatal closure is induced by bulk leaf water stress in a feedback response (Cowan 1977), and the form of the relationship is generally found to be a thresholdtype response (Avissar et al. 1985) with decreasing leaf water potential.

Wind speed influences stomatal conductance. Some species respond to increasing wind speed with stomatal closure and some with stomatal opening (Caldwell 1970; Kramer 1983). These responses are attributed to changes in humidity near the leaf because of changes in the boundary layer (Sheriff 1979) or changes in the internal $\mathrm{CO}_{2}$ concentration (Meidner and Mansfield 1968).

Reductions in stomatal conductance have been observed with deficiencies in a variety of soil nutrients and, in particular, nitrogen, phosphorus, and potassium (Sheriff 1979). Plants also respond to stressful conditions of temperature and water status by hardening to the conditions. Adjustment in stomatal conductance is one manifestation of hardening in response to stress (Tumer and Kramer 1980).

Major biotic factors that control stomatal conductance are physiological leaf age and hormones. The responsiveness of stomates depends on the physiological age of 
the leaf. Stomata of older leaves of some species do not open as rapidly, or as widely as in younger leaves (Hsiao 1975; Kramer 1983). Tazaki, Ishihara, and Usijima (1980) found that the stomata of older mulberry leaves would not close. The hormone $A B A$ has been found to induce stomatal closure usually in association with water stress (Kramer 1983). In some plants, stomatal closure is not correlated with ABA levels (Ackerson 1980), but may be related to other substances such as farnesol (Mansfield et al. 1978) and phaseic acid (Sharkey and Raschke 1980). Cytokinins cause stomatal opening and also retard senescence (Farquhar and Sharkey 1982). This may be related to the observed effect of leaf age on stomatal conductance.

Life history strategies of various and land species control how much water can be transpired. The two basic life history strategies of vascular plants found in arid systems are drought avoidance and drought tolerance (Schulze 1983). Annuals and deciduous perennial grasses and shrubs are drought avoiders, withstanding drought as seeds in the case of the annuals, and in the leafless state in the case of perennial grasses and shrubs. In both cases, transpiration is curtailed as a consequence of such quiescent behavior.

The major drought-avoidance species expected to grow on proposed barniers are cheatgrass ( $B_{\text {. tectorum) }}$ an annual; bluebunch wheatgrass (Agropyron spicatum) and Sandberg's bluegrass (Roa secunda), perennial deciduous grasses; spiny hopsage (Gravia spinosa), bitterbrush (Purshia tridentata), green rabbitbrush (Chrysothamnus vicidiflorus) and grey rabbitbrush (Chrysothamnus nauseosus), deciduous shrubs. Drought tolerators maintain foliage through stressful periods by adjusting osmotic potentials and maintaining cell turgor. Although drought tolerators maintain foliage, they transpire very little water under water stress. The only species expected to grow on barriers that maintain some foliage is A. tridentata. Poikhilohydrics (cryptogams) such as lichens and mosses are inactive when dry and active when wet.

\subsubsection{Model of Kuppers and Schulze (1985)}

The Kuppers and Schulze (1985) model couples $\mathrm{CO}_{2}$ assimilation and stomatal conductance to water to environmental factors. It predicts diumal assimilation and conductance for Scots pine (Pinus silvestris $L$.). The model consists of two submodels, one describing the response of $\mathrm{CO}_{2}$ uptake to light and temperature, the 
other describing the response of leaf conductance to temperature and humidity. The submodels are joined by the linear relationship between $\mathrm{CO}_{2}$ uptake and leaf conductance at short-term variation of light. From the humidity response of leaf conductance and the demand function (Raschke 1979) of $\mathrm{CO}_{2}$ in the mesophyll, the effect of stomata on the diffusion of $\mathrm{CO}_{2}$ between leaf and air is determined. The endpoint of the analysis of this model will be an estimate of internal $\mathrm{CO}_{2}$ concentration as a function of light, temperature, and humidity. Because the diffusivity of $\mathrm{CO}_{2}$ can be correlated with that of some gaseous air pollutants, this model should also provide predictions of air pollutant internal concentrations. $\mathrm{CO}_{2}$ assimilation is related to light and temperature as follows:

$$
\left.A_{(I, T)}=A_{\max }(T)\left[1-e^{-a_{1}\left(I-I_{C}\right.}(T)\right)\right]
$$

where $A_{(I, T)}$ is the light response of $\mathrm{CO}_{2}$ assimilation at a given leaf temperature (T), I is light, and $\mathrm{I}_{C(T)}$ is the light compensation point at $T$. The parameter $a_{1}$ determines the curvature of the light relationship and was found to be independent of temperature.

The light saturated response of $\mathrm{CO}_{2}$ assimilation to temperature $\left(\mathrm{A}_{\max }(\mathrm{T})\right.$ ) was described with the following polynomial regression:

$$
A_{\max }(T)=a_{2} T^{3}+a_{3} T^{2}+a_{4} T+a_{5}
$$

and the temperature dependence of the light compensation point is given as:

$$
I_{C}(T)=e^{\left(a_{6} T+a_{7}\right)}
$$

With these three equations it is possible to describe the response surface of $\mathrm{CO}_{2}$ uptake to light and temperature. 
Independent of the above submodel, the temperature response of dark respiration was determined as:

$$
A(T, I=0)=-a_{8} T^{a g}
$$

In the second submodel, the response of leaf conductance to temperature and humidity is determined. The response to leaf temperature at low leaf-air vapor concentration differences $(\Delta w)$ is described as:

$$
g_{\max }(T)=e^{\left(b_{1} T+b_{2}\right)}
$$

where $g_{\max }(T)$ is the response of leat conductance when it is maximal because of low $\Delta w$, to leaf temperature.

The relationship between leaf conductance and $\Delta w$ was described as a feedforward response (Farquhar 1978) as follows:

$$
\left.g_{(\Delta w)}=\left[g_{0}-\left(g^{*} / \Delta w^{*}\right) \Delta w\right] / 1-\left(2-g_{0} / g^{*}\right) \Delta w / \Delta w^{*}\right]
$$

where $\Delta w^{*}$ is the leaf-air water vapor concentration difference at which transpiration is maximal, and $\mathrm{g}^{*}$ is the corresponding leaf conductance. For the determination of $\Delta \mathrm{w}^{*}$, the following regression type was determined:

$$
g(\Delta w)^{-1}=e^{\left(b_{3} \Delta w+b_{4}\right)}
$$


Extrapolation to $\Delta \mathbf{w}=0$ yielded $g_{0}$. The position of maximal, transpiration is given by $\Delta w^{*}=b_{3}{ }^{-1}$. Thus, $g^{*}$ can be determined, and Equation (6) can be solved.

The two submodels can be linked at any given combination of light and temperature as follows:

$$
g_{(I, T)}=\left[\left[g_{\max }(T)-g_{(A=0, T)}\right] A_{(I, T)} / A_{\max }(T)\right]+g_{(A=0, T)}
$$

where $g_{(A=0, T)}$ is the leaf conductance at light compensation for $\mathrm{CO}_{2}$ uptake. It was found that $g_{(A=0, T)}$ was linearly related to $g_{\max }(T)$ and could be parameterized as:

$$
g(A=0, T)=p g \max (T)
$$

The relationship between assimilation and conductance is given by:

$$
A=\left(C_{a}-C_{i}\right) g_{\Delta w} / 1600
$$

where $\mathrm{C}_{\mathrm{a}}$ is ambient $\mathrm{CO}_{2}$, and $\mathrm{C}_{\mathrm{j}}$ is the internal $\mathrm{CO}_{2}$ concentrations. The factor 1600 accounts for the difference of diffusivities of $\mathrm{H}_{2} \mathrm{O}$ and $\mathrm{CO}_{2}$.

For different leaf temperatures and light levels it was assumed that the relative response of stomata to humidity did not vary. A similar limitation of $\mathrm{CO}_{2}$ assimilation was assumed because of stomata for the same $\Delta w$, but different temperatures and light levels were assumed.

The prediction of transpiration $(E)$ is dependent on the vapor pressure gradient (vpg) and stomatal conductance and is given by: 


$$
E=v p g g_{\Delta w}
$$

\subsubsection{Model of Avissar et al. (1985)}

The Kuppers and Schulze (1985) model is accurate, but too complicated. It does not include the effect of water potential on stomatal conductance. The Avissar et al. (1985) model includes a relationship between soil water potential and stomatal conductance in addition to the effects of vapor pressure deficit, temperature, and light. It is simpler than the Kuppers and Schulze model, but does not consider assimilation and is not as accurate. However, the Avissar et al. model may be acceptable. Their model relates stomatal conductance to solar global radiation, leaf temperature, vapor pressure gradient, ambient $\mathrm{CO}_{2}$, and soil water potential for tobacco (Nicotania tobaccum).

The general equation in the Avissar et al. model used to predict relative stomatal conductance is as follows:

$$
d_{r s}=\left[d_{s M}+\left(d_{s M}-d_{s m}\right) R^{i} T h V^{f} c^{f} p\right] / d_{s M^{1}}
$$

where $\quad d_{r s}=$ the relative stomatal conductance $\left(\mathrm{ms}^{-1} / \mathrm{ms}^{-1}\right)$

$\mathrm{d}_{\mathrm{sm}}=$ minimal conductance that occurs through the leaf cuticle when the stomata are closed

$d_{S M}=$ maximal stomatal conductance obtained when stomata are completely opened

$f_{i}$ functions $=$ influence of a specific environmental factor on the conductance ( $\mathrm{R}$ for solar global radiation, $\mathrm{T}$ for leaf 
temperature, $\mathrm{V}$ for vapor pressure deficit, $\mathrm{C}$ for air $\mathrm{CO}_{2}$ concentration, and $P$ for soil water potential).

The mathematical expression used for each of the $f_{i}$ functions is as follows:

$$
f_{i}=1 /\left\{1+\theta\left[-S\left(X_{i}-b\right)\right]\right\}
$$

where $\quad i=$ the environmental factor

$$
\begin{aligned}
& b=\text { the abscissa at } f_{i}=1 / 2 \\
& S=\text { the slope of the curve at this point } \\
& X_{i}=\text { the intensity of the factor } i .
\end{aligned}
$$

To use this model, $d_{s m}, d_{S M}, b$, and $S$ must be determined. In the Avissar et al. model, $d_{s m}=0.05 \mathrm{~cm} \mathrm{~s}^{-1}$, and $d_{S M}=0.93 \mathrm{~cm} \mathrm{~s}^{-1}$.

To predict transpiration, $d_{r s}$ must be converted back to absolute values $\left(d_{s}\right)$. The equation for transpiration is then:

$$
E=v p d d_{S}
$$

The descriptions of gas exchange models in this section provide only two examples from among many. These models provide only partial answers to predicting evapotranspiration because they focus on stomatal mechanisms. To fully understand the process of transpiration at the whole plant level, other plant factors need to be considered in the context of whole plant system models. 


\subsection{GAS EXCHANGE WHOLE PLANT SYSTEM MODELS}

System models of plant processes are numerous and most highly developed for agronomic species. Reynolds and Acock (1985) recently reviewed 46 system models for plants and concluded that the minimum set of plant processes necessary for such models includes photosynthesis, morphology, phenology, respiration, nutrients, water, growth, and partitioning. How these processes may be linked is shown in Figure 2.1, using a diagram of the PRECO model, as described in Reynolds et al. (1988). 


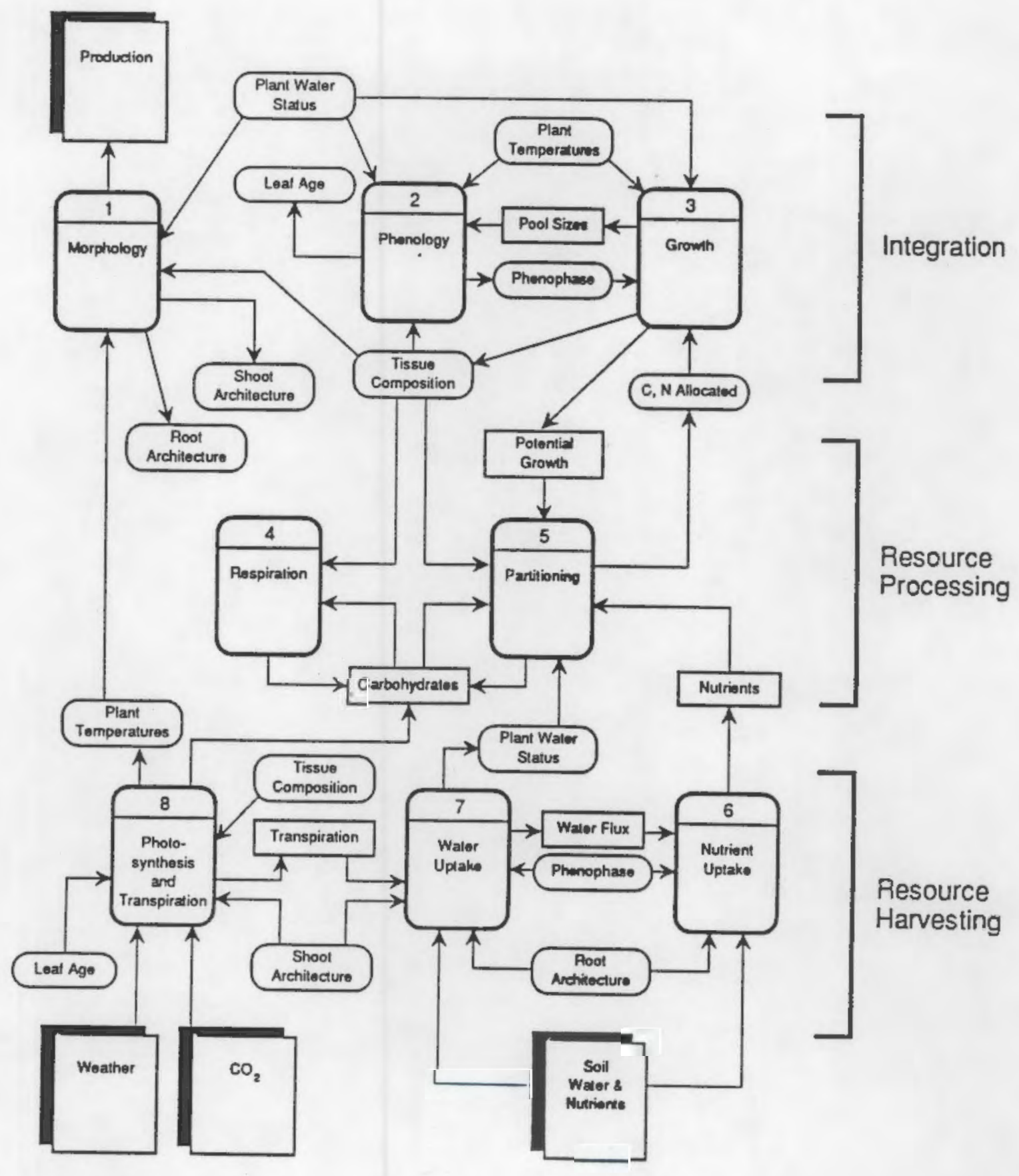

FIGURE 2.1. Diagram of the PRECO Model. Modules are represented by the eight numbered boxes (after Reynolds et al. 1988). 



\subsection{GAS EXCHANGE EXPERIMENTAL PLANS}

Gas exchange technology generally has been used to measure $\mathrm{CO}_{2}$ and $\mathrm{H}_{2} \mathrm{O}$ flux in plant systems. Early systems concentrated on controlling $\mathrm{CO}_{2}$ and temperature within chambers over crops (Louwerse and Eikhoudt 1975; Brown and Trlica 1977; Redmann 1978). These systems did not control evapotranspiration and produced gross measurement errors because of inaccurate sensors and control. Recent improvements allow for the concurrent measurement and control of temperature, wind speed, $\mathrm{CO}_{2}$, and $\mathrm{H}_{2} \mathrm{O}$ (Caldwell et al. 1983; McKinion and Hodges 1985), which make it possible to develop functional relationships between driving environmental variables and evapotranspiration. Knowledge of these relationships is essential if models of evapotranspiration are to be related to short time scale meteorological data.

The application of plant gas exchange technology to barrier development will enable us to develop a predictive model that is sensitive to changes in the barrier environment. An improved plant gas exchange system developed by PNL also allows for concurrent measurement and control of temperature, vapor pressure density, wind speed, and $\mathrm{CO}_{2}$, which make it possible to determine the functional relationships between evapotranspiration and environmental driving variables.

Plans for two bamier development experiments using PNL gas exchange systems are described in this section. In one experiment, the whole-plant gas exchange system will be coupled with small-tube lysimeters at the Small-Tube Lysimeter Test Facility to measure and model the effects of gravel mulch and enhanced precipitation on evapotranspiration. In the second experiment, a single-leaf gas exchange system, and other instruments for measuring plant water status and leaf area, will be used to collect data for model development on McGee Ranch shrubs.

\subsection{COUPLED GAS EXCHANGE SYSTEM AND SMALL-TUBELYSIMETER STUDIES}

This experiment uses gas exchange technology to measure and model evapotranspiration in conjunction with the small-tube lysimeter studies, designated EROD-1 in Wing (1988) and described in Waugh and Link (1988). The lysimeter study is designed to determine the effects of gravel layers, water, and vegetation on soil 
water storage, drainage, and evapotranspiration. In the lysimeter studies, if precipitation, storage, and drainage terms are known, then evapotranspiration can be estimated by subtraction.

Gas exchange chambers have been successfully used in conjunction with lysimeters yielding comparable values of evapotranspiration (Reicosky et al. 1981; Peterson, Loudon, and Merva 1985). Gas exchange technology makes it possible to directly and economically measure evapotranspiration under uncontrolled or controlled conditions. It can be used to verify that the subtraction method is accurate and to develop functional relationships between driving environmental variables and evapotranspiration for modeling.

The gas exchange component of the small-tube lysimeter studies will proceed in three phases. In Phase $\mathrm{I}$, the gas exchange system will be constructed and tested. Phase II will use the gas exchange system to test treatment effects in the experimental design. In Phase III, the gas exchange system will be used to monitor diurnal evapotranspiration and determine the functional relationships between evapotranspiration and environmental driving variables to parameterize predictive models of evapotranspiration.

\subsubsection{Ehase l: System Construction and Testing}

\subsubsection{System Construction}

Chamber walls will be constructed of acrylic plastic covered with a clear Teflon film, which reduces photosynthetically active radiation by only $5 \%$. Non-stainless steel components within the chambers will be nickel plated to reduce gas adsorption (Bloom et al. 1980). The chambers will be sealed by screwing a stainless steel sleeve onto the chamber. A sample of chamber air will be returned to the infrared gas analyzer (IRGA) for $\mathrm{CO}_{2}$ measurement and the dewpoint hygrometer for $\mathrm{H}_{2} \mathrm{O}$ measurement by a pump. Chamber temperature will be controlled to set-point, or to track ambient temperature by computer-controlled, water-cooled Peltier heat exchangers. Chamber air temperature will be measured with fine-wire thermocouples. Boundary layer resistance can be controlled by varying the wind speed within the chambers. Average canopy leaf temperature will be measured with five fine-wire thermocouples randomly distributed in the canopy and placed in the mesophyll. 
Outside air temperature will be measured with fine-wire thermocouples at canopy height. Ambient air relative humidity will be measured at canopy height with a thin-film capacitance sensor (Vailsala Co.). Relative humidity of the air returning from the chambers will be measured with a dewpoint hygrometer (General Eastern Co.). The capacitance humidity sensor will be calibrated periodically against the dewpoint hygrometer. The capacitance sensor will provide the signal for control of chamber humidity when tracking ambient conditions. Chamber humidity will be controlled by varying the flow rate of incoming dry air. Air lines will be insulated and or heated to prevent water vapor condensation. Photosynthetically active radiation will be measured at a height of $1.5 \mathrm{~m}$.

Gas exchange will be monitored by placing chambers over entire lysimeters. Computers will be used to control chamber conditions, serially sample gas, and acquire data. Filtered ambient air will be drawn from a height of $2 \mathrm{~m}$ by oil-less compressors, cooled with a water jacket, passed through heatless dryers (Puregas Co.) and passed to a large pressurized mixing tank. The dryers remove a substantial portion of the $\mathrm{CO}_{2}$ along with the water vapor. To compensate for this and for $\mathrm{CO}_{2}$ uptake by the plants, pure $\mathrm{CO}_{2}$ will be metered into the incoming air to supply $350 \pm$ $10 \mathrm{ppm} \mathrm{CO}_{2}$. All air-line components will be constructed of stainless steel piping or Tefion to prevent adsorption of $\mathrm{CO}_{2}$ and $\mathrm{H}_{2} \mathrm{O}$ (Bloom et al. 1980). Flow rates will be controlled and measured with computer-controlled mass-flow controllers (Tylan Co.).

Analog signals will be digitized with a Campbell Scientific CR7x data acquisition system. Data will be acquired every 10 seconds, averaged over a 5minute period, and stored on a floppy disc with an IBM AT computer. The data aquisition and instrument control program will be written in Turbo Pascal. The program will control solenoids for the serial interrogation of the chambers and for periodic automatic recalibration of the IRGA. Chamber temperature, relative humidity, and flow rate will be controlled by Omega controllers.

\subsubsection{System_esting}

The gas exchange system will be tested to ensure that measured evapotranspiration is attributable to the lysimeter column and not to leaks or material effects. It is likely that evapotranspiration will be small over dry surfaces, so the measurement technique will have to be accurate. Initial observations of the two 
dewpoint hygrometers used to measure water vapor before and after the chamber indicate that they are within $0.1^{\circ} \mathrm{C}$ when exposed to the same stream of air.

The first of four gas exchange chamber tests will seal the chamber over a nonevaporative, inert surface and operate the system to determine if zero $\mathrm{H}_{2} \mathrm{O}$ and $\mathrm{CO}_{2}$ exchange can be maintained. The seals connecting the gas exchange chamber to lysimeter prototypes will be tested second. Measurement of evapotranspiration in the chamber must be attributable to the lysimeter column, not to leaks.

The sensitivity of the system to known water loss rates will be tested third. Evaporation from a surface will be monitored concurrently by the gas exchange system and a potometer placed inside the chamber. A potometer is a tissue paper wick attached to a column of water in a graduated cylinder. Evaporation from the potometer can be monitored by noting the volume of water lost over time. The amount of water monitored by the gas exchange system integrated over the observation period should correspond with that observed with the potometer (Tranquillini and Caldwell 1972). Carbon dioxide exchange will be verified in the fourth test by metering a known concentration of $\mathrm{CO}_{2}$ into the chamber at a constant and known flow rate. The amount of $\mathrm{CO}_{2}$ measured with the gas exchange system should correspond with the metered source of $\mathrm{CO}_{2}$.

\subsubsection{Phase ll: TreatmentEffects}

The experimental design for the lysimeter experiment is given in Waugh and Link (1988) and is summarized in Table 3.1.

Treatment effects for lysimeters containing B. tectorum will be tested with the gas exchange system. Observations will consist of steady-state measurements of the rate of evapotranspiration under standard conditions imposed by the control mechanism of the gas exchange system. Measurement under standard conditions means that atmospheric conditions in the chambers will be constant for all replicates. Standard conditions will be constant air temperature, vapor pressure density, wind speed, $\mathrm{CO}_{2}$ concentration, and light, which will be determined after we have gained experience with the gas exchange system. It will take about 1 hour to monitor one 
TABLE 3.1. Treatment Structure for the Small-Tube Lysimeter Experiment

\begin{tabular}{|c|c|c|c|c|c|c|c|c|c|}
\hline \multirow{3}{*}{$\begin{array}{l}\text { Treatment } \\
\text { Combinations }\end{array}$} & \multirow{2}{*}{\multicolumn{2}{|c|}{ Barrier Layering }} & \multirow{2}{*}{\multicolumn{2}{|c|}{ Vegetation }} & \multicolumn{3}{|c|}{ Surface Treatments } & \multirow{2}{*}{\multicolumn{2}{|c|}{ Precipitation }} \\
\hline & & & & & \multirow{2}{*}{$\begin{array}{l}\text { Admix } \\
\text { Gravel }\end{array}$} & \multirow{2}{*}{$\begin{array}{l}\text { Surface } \\
\text { Gravel } \\
\end{array}$} & \multirow{2}{*}{$\begin{array}{l}\text { Sand } \\
\text { Deposition }\end{array}$} & & \\
\hline & Graded & Bimodal & Bare & Cheatgrass & & & & Control & $2 \times($ sat) \\
\hline 1 & $\mathrm{x}$ & & $x$ & & & & & $x$ & \\
\hline 2 & $\mathrm{x}$ & & $\mathrm{x}$ & & & & & & $\mathrm{x}$ \\
\hline 3 & $\mathrm{x}$ & & $\mathrm{x}$ & & $x$ & & & $\mathrm{x}$ & \\
\hline 4 & $x$ & & $x$ & & $x$ & & & & $x$ \\
\hline 5 & $x$ & & $x$ & & & $x$ & & $x$ & \\
\hline 6 & $x$ & & $x$ & & & $x$ & & & $x$ \\
\hline 7 & $\mathrm{x}$ & & & $\mathrm{x}$ & & & & $\mathrm{x}$ & \\
\hline 8 & $x$ & & & $x$ & & & & & $x$ \\
\hline 9 & $\mathrm{x}$ & & & $x$ & $\mathrm{x}$ & & & $\mathrm{x}$ & \\
\hline 10 & $x$ & & & $x$ & $x$ & & & & $\mathrm{x}$ \\
\hline 11 & $x$ & & & $x$ & & $x$ & & $x$ & \\
\hline 12 & $x$ & & & $x$ & & $x$ & & & $x$ \\
\hline 13 & $x$ & & $x$ & & & & $x$ & & $x$ \\
\hline 14 & $x$ & & & $x$ & & & $x$ & & $x$ \\
\hline 15 & & $x$ & & & & & & $x$ & \\
\hline 16 & & $x$ & & $\mathrm{x}$ & & & & & $\mathrm{x}$ \\
\hline
\end{tabular}


lysimeter. Five observations per day or about 100 observations per month will be completed. Because the lysimeters will be randomly located in the field, the effect of days on the response will also be randomized. With a multiple chamber system, the time required to complete the observations and variation within treatments would be reduced.

\subsubsection{Phase lll: Modeling}

The purpose of Phase III is to measure functional relationships between evapotranspiration and environmental driving vaniables to use in predictive models of water movement through barniers.

Experiments to parameterize models of transpiration rates are best done in the field, not in the laboratory. In the field, some determinants of transpiration change slowly through the season while others change diurnally. The basic strategy for parameterizing transpiration rate models is to construct multidimensional response surfaces at points through the season and then consider such parameters as a function of levels of the slowly changing determinants. In the process of constructing response surfaces, some determinants of transpiration will be found to contribute little to the explanation of variation of transpiration and can be ignored.

\subsubsection{Slowly Changing Variates}

The supply of water to roots is a slowly changing variate and will be measured using depth with soil psychrometers or a neutron probe. Root growth will be monitored versus time with periscopes inserted into the root zones. Root zone temperature will be monitored with thermistors. Soil nutrient status will be determined by standard agricultural methods. Xylem water potential will be measured with a pressure bomb.

Phenological observations will be taken when gas exchange data are collected. Leaf area will be measured in conjunction with gas exchange data. Leaf area will be measured nondestructively with an automated, inclined point frame periodically to monitor growth and leaf phenology. The automated inclined point frame provides a primary estimate of leaf area. Correlations with harvested leaf area are above $90 \%$ (Caldwell et al. 1983). Accuracy in the system will be ensured by harvesting and 
correlation. At the end of the season plants will be destructively harvested to assess shoot-to-root ratios.

\subsubsection{Bapidly Changino Variates}

The relationship of whole plant stomatal conductance to its determinants will be parameterized with controlled experiments performed in the field. This will be done by changing one variable while holding others constant. At high light intensity, high vapor pressure density, and high wind speed, temperature will be varied to obtain a temperature response curve. At optimal temperature, high vapor pressure density, and high wind speed, light will be varied to obtain a light response curve. At high light intensity, optimal temperature, and high vapor pressure density, wind speed will be varied to obtain a wind speed response curve. At high light, optimal temperature, and high wind speed, vapor pressure will be varied to obtain a vapor pressure gradient response curve. These response curves will be generated at midday when xylem water potential changes little. Finally, a xylem water potential response curve will be generated by holding temperature, light, vapor pressure density, and wind speed constant. These data will form the basis of a five-dimensional response surface of which parameters will be estimated by multiple regression.

\subsubsection{Environmental Monitoring}

Meteorological data, which are acquired every $30 \mathrm{~min}$, will include air temperature at $1.5 \mathrm{~cm}$ above ground level, surface soil temperature, soil temperature with depth, and relative humidity at $1.5 \mathrm{~cm}$ above ground level and at canopy height; short-wave radiation, net radiation, photosynthetically active radiation; and wind speed at $2 \mathrm{~m}$ above ground level and at canopy height. These data are currently being collected at the Field Lysimeter Test Facility.

\subsection{MCGEE RANCH PLANT WATERRELATIONS}

The objective of this study is to characterize transpiration, photosynthesis, plant water relations, leaf area, growth, and soil water status during late winter to early summer. This information will be used to improve the plant component of the UNSAT- 
$\mathrm{H}$ code and will form the basis for a comparison between the undisturbed vegetation of McGee Ranch and the newly established plants located on the large lysimeters of the Field Lysimeter Test Facility. The realization that it is impossible to create the variety of possible plant communities that could exist on the proposed barrier led us to consider studies in existing plant communities. Although layered soil structures exactly like those proposed for the barrier are not likely to be found in natural habitats, the fine textured soils that will compose the top layer of the barner can be found. Because McGee Ranch soils were chosen as the source of topsoil for the barner, McGee Ranch was chosen to conduct natural anaiog studies (Wing 1988).

The McGee Ranch is located northwest of the Yakima Barricade in Section 30, Township 13 North, Range 25 East bordered on the east and south by State Highways 240 and 24, respectively. Soil characteristics of the area are described in detail in Waugh and Link (1988). McGee Ranch vegetation is composed of perennial shrubs and grasses and annual grasses with a minor component of forbs. The shrubs are $A$. tridentata and $G$. spinosa. The majority of 1988 studies are being conducted in an area of McGee Ranch where shrubs are prominent. This area represents a likely climax community of species that are characteristic of the MCGee soils. Although some question exists about the likelihood of this community re-establishing itself on the barrier given the invasive strength of the annual grass $B$. tectorum on disturbed soils (Daubenmire 1970), the possibility cannot be ignored given the long design life of the barrier. Studying perennial shrubs is further supported because they are relatively deep rooted in comparison to $\mathrm{B}$. tectorum and thus will interact with soil water differently.

Work at McGee Ranch was initiated in 1986 with the placement of neutron probes around shrubs. Mean percent cover at that time was $4.0 \%$ A tridentata and $17.3 \% \mathrm{G}$. spinosa. as estimated by the method of Daubenmire (1959). Although the percent cover of $A$. tridentata was less than that of $G$. spinosa there were more $A$. tridentata individuals. A model of leaf area was developed for the shrubs by relating harvested leaf areas to shrub dimensions. To estimate leaf area on a ground-area basis $\left(\mathrm{m}^{2} / \mathrm{m}^{2}\right)$, shrub dimensions were measured in $10,50 \mathrm{~m}^{2}$ randomly located quadrats, and then leaf areas were computed. Leaf area estimated on a ground-area basis for $A$. tridentata $(0.167 \pm 0.074)$ was more than three times that of $G$. spinesa $(0.049 \pm 0.024)$. These estimates were gathered on June 17,1986 , and are accurate only for that time of year because leaf area is dynamic with growth and loss of leaves 
through a growing season. Neutron probe data were gathered on July 17 and August 1,1986 , in the old field and shrub sections of McGee Ranch. Randomly located probes at these sites revealed that at the $150 \mathrm{~cm}$ depth, the old field had more water $(10 \%)$ than the shrub site $(5 \%)$. Intensive monitoring around individual shrubs showed considerable variation among the shrubs. At the $150 \mathrm{~cm}$ depth, one A tridentata individual had a soil water content of $5 \%$, the other A. tridentata $10 \%$, and the $\mathbf{G}$. spinosa $6 \%$. There was no significant difference in soil water content between observation dates.

\subsubsection{Methods}

\subsubsection{Soil Water Content}

Soil water content will be measured by neutron probe using the access ports already in place (eight around each of two A tridentata, eight around one G. spinosa, six randomly located in the shrub section and six randomly located in the old field). Water content can be measured monthly to a depth of $300 \mathrm{~cm}$ during the course of the experiment.

\subsubsection{Gas Exchange}

Gas exchange data will be gathered for A. tridentata and $\mathrm{G}$. spinosa. The gas exchange system (DDG Inc.) measures net photosynthesis and stomatal conductance of twig tips. It is a null balance system that controls the $\mathrm{CO}_{2}$ concentration, vapor pressure gradient, and temperature of the exposure system. Observations will be made monthly of five replicates of each species at standard chamber conditions to determine changes in net photosynthetic capacity and stomatal conductance. Diurnal gas exchange data will be gathered at low soil water stress conditions in April and at high soil water stress conditions in June for both species to compare the response of these species to soil water stress. Data for modeling parameterization will be gathered for both species by controlling chamber conditions and obtaining response curves for one driving factor while holding others constant. Light, temperature, vapor pressure gradients and $\mathrm{CO}_{2}$ concentrations can be controlled. Such response curves can also be gathered when soil water stress is low and high as the season progresses. Each of these five driving factors affects net photosynthesis and stomatal conductance. 


\subsubsection{Plant Water Status}

Measurements of plant water potential will be gathered concurrently with the gas exchange data. As soil water becomes limiting, the xylem pressure potential of the plant will drop, which indicates increasing plant water stress. Generally, as xylem pressure potential drops, stomatal conductance and net photosynthesis also will drop. Plants that are adapted to anid conditions will adjust osmotic potential in response to lower plant water potential to maintain cell turgor, and thus maintain rates of net photosynthesis and stomatal conductance. The ability of these two species to osmotically adjust to water stress will be determined. This is done by determining the xylem pressure potential of a twig tip with a Scholander (1965)-type pressure bomb (Soil Water Equipment Co.), freeze the leaf material on dry ice, and then determine the osmotic potential in a thermocouple psychrometer (Decagon Devices inc.). Turgor pressure can then be computed as follows:

$$
P_{p}=P_{\text {tot }}-P_{\pi}
$$

where $P_{p}$ is the turgor potential, $P_{\text {tot }}$ is the xylem pressure potential, and $P_{\pi}$ is the osmotic potential.

\subsubsection{Leaf Area and Growth}

The other major plant factor that determines photosynthetic rates and transpiration is leaf area. The gas exchange data to be collected will be expressed by leaf area for the exposed branch tips. To estimate the net photosynthesis and transpiration for whole plants, the leaf area of the whole plant needs to be determined. Because leaf area growth is a dynamic process, leaf area will be determined monthly for three individuals of each species using an automated point frame (Caldwell et al. 1983). Gas exchange estimates obtained on twig tips are not reliably extrapolated to whole plants because of canopy effects, but will provide relative estimates for comparison. The whole plant gas exchange system being developed will provide such estimates in association with whole plant leaf area estimates. Because whole 
plant leaf area is tedious to measure with the point frame, some double sampling approaches will be investigated, as has been done in the past with destructive harvesting. In addition to leaf area estimates, Ceres units (Beedlow et al. 1986) have been used on three individuals of both species to obtain real-time growth estimates. These units continuously measure changes in stem diameter and will provide comparative data on growth, which is expensive to obtain by any other method. 


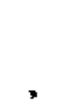

, 


\subsection{BELATIONSHIP TO OTHER TASKS IN THE PROTECTIVE BARRIER DEVELOPMENT PROGRAM}

This section describes the relationship between the plant evapotranspiration tasks described in Section 3.0 for small-tube lysimeters and McGee Ranch studies with other Protective Barrier Development Program tasks described in Wing (1988). The importance of plant studies to assess the performance of proposed protective barrier designs necessarily requires integration with most of these tasks.

\subsection{ANIMAL BURROW CHABACTERISTICS (B|O-2)}

The purpose of this task is to characterize vertebrate and invertebrate animal burrows and determine how these burrows may impact the barrier. Burrows and biological channels provide zones in which plant roots will concentrate (Bohm 1979). In addition, the soil transferred to the surface provides a seed bed in which particular plant species can germinate and be successful in contrast to undisturbed areas (Koide, Huenneke, and Mooney 1987). It is important to know how biological channels interact with root systems because there is the possibility that roots may be able to more efficiently access water than they might in undisturbed soils and, consequently, will influence transpiration rates. The effect of mounds on plant species composition and growth is also required for plant transpiration studies.

\subsection{BURROWING EFEECTS ON WATER INFILTRATION (BIO-3)}

How water infiltrates into the soil will directly affect where roots will grow and, consequently, how much water the plants will transpire.

\subsection{PLANT INTRUSION TESTS (BIO-5)}

The depth of roots in the barrier will influence how much water plants can transpire. If plants can only access shallow depths, their access to water will be restricted and, thus, they will transpire less water than they might if their roots could access deeper soil layers. In addition, a shallow rooting zone will favor shallow-rooted species such as $\mathbf{B}$.tectorum over deeper-rooted species such as A.tridentata. Thus, information on root penetration is needed to properly predict transpiration. The 
research discussed in this document is being performed to address some of the technical concerns identified in task WTR-2.

\subsection{RREDICTION AND INTEGRATION (BIOPORT MODEL) (B|O-6)}

The predictions from this model will be necessary to accurately predict plant transpiration, as described for other BIO tasks.

\subsection{PLANT TRANSPIBATION DATA COLLECTION AND MODELING (WTR-2)}

This task, as written, focuses on similar research as described in this plan. Work done on perennials established on Field Lysimeter Test Facility lysimeters will be compared with work done on the naturally established perenniais being studied at McGee Ranch.

\subsection{GRAVEL MULCH STUDIES (EROD - 1 )}

Transpiration studies relative to this task have been discussed in detail in this document and in Waugh and Link (1988). The admix portion of this task also is relevant to transpiration studies. The admix treatments will influence the amount of water stored in the soil and, consequently, will influence the amount of water plants will transpire. In addition, differences in stored water will influence the types and abundance of plants that occur on the different admix treatments.

\subsection{WIND TUNNEL TESTS (EROD-2)}

This task focuses on the effects of wind on surface stability and the consequences for barrier performance. The proposed tests are relevant to plant community structure and, consequently, to transpiration on the barrier. In addition, wind directly affects transpiration. The effect of wind on transpiration is rarely studied because of the lack of wind tunnel facilities. However, the PNL wind tunnel facility provides the possibility for such studies and, because significant wind intensity is a common phenomenon at Hanford, such studies have potential importance. Also, the type of plant cover will influence wind erosion of the barrier surface. 


\subsection{WATEREROSION STUDIES (EROD-3)}

Water erosion will change the plant community structure and, consequently, transpiration from the barrier. In addition, differing plant communities will influence water erosion.

\subsection{DEPOSITION OF WIND-BLOWN PARTICLLES STUDIES (EROD-4)}

Deposition of wind-blown particles, especially sand dunes, will greatly affect the plant community structure and, consequently, transpiration from the barrier. It will be important to know the community structure likely to exist with dunes and then characterize transpiration from such a community.

\subsection{APPLICATIONS OF COMPUTER MODELS (MOD-1)}

Model development is planned in conjunction with the two plant evapotranspiration tasks described in this plan. For example, evapotranspiration work will be formulated as a subroutine for the larger UNSAT-H code. The modeling will also aid in directing the plant model development work by using sensitivity analysis to determine the most important processes to examine. Models will eventually be able to simulate plant growth and plant transpiration.

\subsection{MODEL VALIDATION (MOD-2)}

Data gathered in the plant transpiration tasks will also validate data sets. It is anticipated that as the model is developed, specific validation tasks will be designed.

\subsection{ARMORED-SURFACE ANALOG FIELD STUDIES (NAT-2)}

Sites such as bergmounds armored with gravel possess important characteristics for barnier development. Because these armored surfaces have a characteristic plant community, it will be important to obtain information about the transpirational characteristics of these species. 


\subsection{MICROBELIEE EFFECTS (NAT-6)}

The effect of localized deflation and deposition around McGee Ranch shrubs on soil water patterns is directly related to transpiration from these shrubs. Data being gathered at McGee Ranch will support this task.

\subsection{PLANT COMMUNITY DYNAMICS (NAT-7)}

This task is central to the natural analog concept. Studies of a variety of plant communities should yield information about the range of possible conditions that will affect the barnier over its design life. Studies of the ecophysiology of these plant communities are required to determine their transpirational capacity. Such studies are under way on the Arid Lands Ecology (ALE) Reserve.

\subsection{LOCALCLIMATE AND VEGETATION CHANGES (CLIM-2)}

Predictions from models developed in this task are required to direct the plant ecophysiology tasks in general. 


\subsection{BEPORTING}

Monthly progress reports will be issued for both studies. Reports detailing the results of the studies will be issued. Depending on the success of the studies, manuscripts for publication in refereed journals will be submitted in FY90.

Projected costs through FY91 are presented in Table 5.1 for the plant gas exchange experiment and in Table 5.2 for the McGee Ranch ecophysiology experiment. In the plant gas exchange experiment, FY89 was spent developing instrumentation for the multiple chamber whole plant gas exchange system and testing lysimeter treatment effects. Lysimeter treatments will continue to be examined, but will emphasize experimentation for model development. In the McGee Ranch ecophysiology experiment, attention will be focused on experimentation for model development and comparative work with Field Lysimeter Test Facility experiments. In FY89, the focus was the effect of soil water on transpiration. In FY90 the focus will be atmospheric factors that influence transpiration, and in FY91 validation data sets will be collected to test models that will be developed. 
IABLE 5.1. Plant Gas Exchange Experiment Costs $(\$ 1000)$

Categony $\quad \frac{\text { FY88 }}{\text { Mat(a) } \mathrm{MP}^{(\mathrm{b})}} \quad \frac{\text { FY89 }}{\text { Mat MP }} \quad \frac{\text { FY90 }}{\text { Mat MP }} \quad \frac{\text { FY91 }}{\text { Mat MP }}$

Plant gas exchange

System materials

Chamber materials

2.0

Air conditioning

3.0

1.0

3.0

Flow controllers

$13.0(\mathrm{c})$

Infrared gas analyzer $13.0(\mathrm{c})$

Air compressor

Hoses and sensors $\quad 5.0$

1.0

8.0

1.0

8.0

Dewpoint hygrometers

Trailer

5.0

Automated point frame

Computer hardware $\quad 2.0$

1.0

6.0

5.0

4.0

5.0

5.0

Single system development

72.0

25.0

2.0

Reports/presentations

1.0

2.0

$2.0 \quad 3.0$

Technical editing

3.0

3.0

35.0

Phase I: Multiple system

3.0

Phase II: Treatment effects

40.0

30.0

Phase III: Model development

$50.0 \quad 50.0$

Yearly Costs

103.0

74.0

169.0

55.0
(a) Materials.
(b) Manpower.
(c) Capital money. 
IABLE 5.2. McGee Ranch Ecophysiology Experiment Costs $(\$ 1000)$

\begin{tabular}{|c|c|c|c|c|}
\hline Category & $\frac{F Y 88}{M a t^{(a)} M^{(b)}}$ & $\frac{F Y 89}{\text { Mat MP }}$ & $\frac{\mathrm{FY} 90}{\text { Mat MP }}$ & $\frac{\mathrm{FY} 91}{\text { Mat } \mathrm{MP}}$ \\
\hline $\begin{array}{l}\text { Materials } \\
\text { Gas tanks } \\
\text { Sample processing } \\
\text { Portable IRGA } \\
\text { Computer hardware }\end{array}$ & 1.0 & 1.0 & $\begin{array}{l}2.0 \\
6.0 \\
1.0\end{array}$ & 2.0 \\
\hline $\begin{array}{l}\text { Fieldwork } \\
\text { Hydroprobe } \\
\text { Gas exchange } \\
\text { Plant water status } \\
\text { Leaf area } \\
\text { Plant growth/phenology }\end{array}$ & $\begin{array}{l}4.0 \\
6.0 \\
4.0 \\
4.0 \\
4.0\end{array}$ & & $\begin{array}{l}4.0 \\
8.0 \\
4.0 \\
8.0 \\
4.0\end{array}$ & $\begin{array}{l}4.0 \\
8.0 \\
4.0 \\
8.0 \\
4.0\end{array}$ \\
\hline Reporting & 5.0 & 5.0 & 5.0 & 5.0 \\
\hline Yearly Costs & 28.0 & 6.0 & 5.0 & 5.0 \\
\hline
\end{tabular}


• 


\subsection{QUALITY ASSURANCE}

A quality assurance plan, OHE-2 Rev. 0 , issued May 26, 1987, will be followed in these studies. Quality control will be further assured by adhering to the calibration schedule for instrumerits and systems described in Table 6.1 .

IABLE 6.1. Quality Controlled Instruments: Calibration and Operation

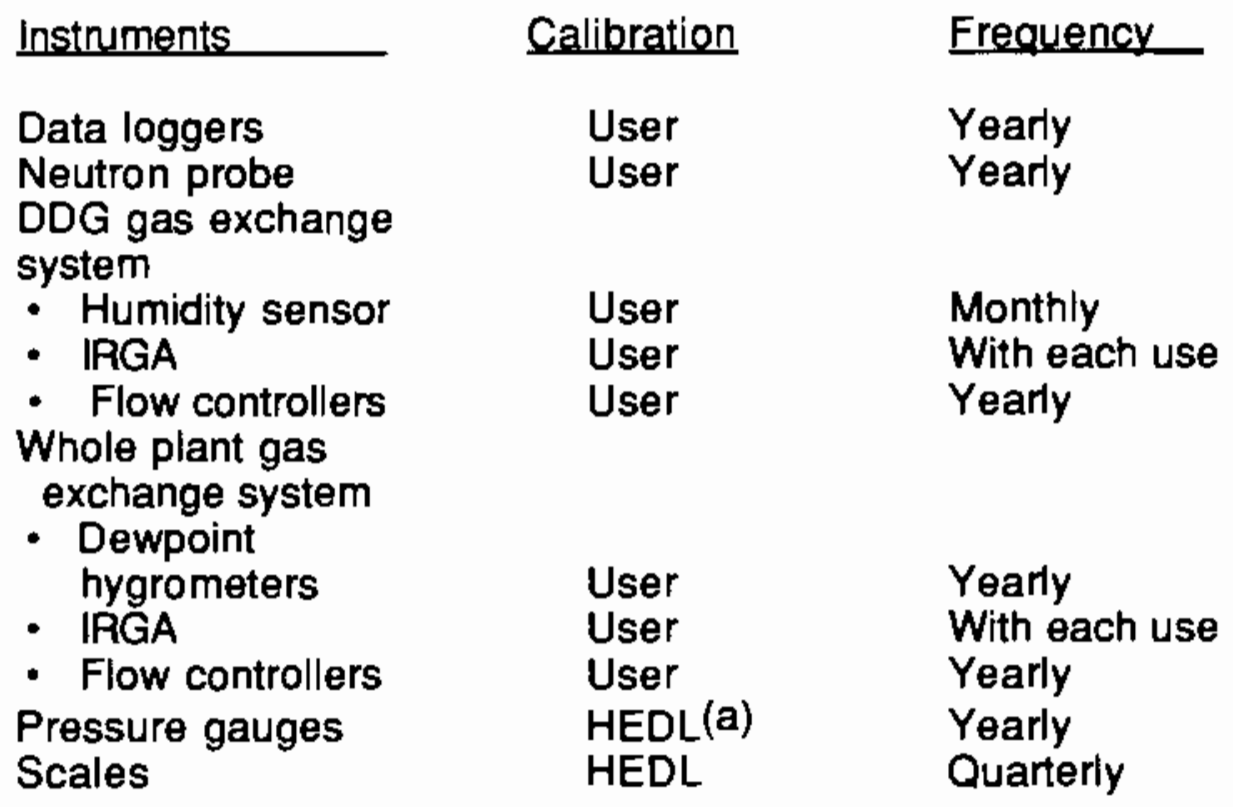

(a) Hanford Engineering Development Laboratory. 



\subsection{SAFETY}

Standard PNL and WHC safety procedures for field monitoring will be followed. The neutron probe will be stored in its designated location at the Arid Lands Ecology Reserve (600 Area). A radiation work procedure has been prepared by PNL and will be followed by all staff members when using this radiatior. source. Compressed air tanks used in this work will be secured with standard tank holders. Electrical wiring used in the field will be periodically inspected for damage caused by use or animals to prevent fires and shocks. Risk and safety forms will be prepared annually to alert PNL and Westinghouse Hanford safety offices of any changes in planned activities. 
,

. 


\subsection{BEEEBENCES}

Ackerson, R. C. 1980. "Stomatal Response of Cotton to Water Stress and Abscisic Acid as Affected by Water Stress History." Plant.Physiol. 48:631-636.

American Society of Agricultural Engineers (ASAE). 1985. Advances in Evapotranspiration: Proceedings of the National Conference on Advances in Evapotranspiration. ASAE Pub. 14-85, American Society of Agricultural Engineers, St. Joseph, Michigan.

Avissar, R., P. Avissar, Y. Mahrer, and B. A. Bravdo. 1985. "A Model to Simulate Response of Plant Stomata to Environmental Conditions." Aaricul. For. Meteorol. 34:21-29.

Bloom, A. J, H. A. Mooney, O. Bjorkmman, and J. Berry. 1980. "Materials and Methods for Carbon Dioxide and Water Exchange Analysis." Plant. Cell. Environ. 3:371-376.

Bohm, W. 1979. Methods of Studving Root_Systems. Springer-Verlag, Berlin.

Brown, L. F., and M. J. Trlica 1977. "Carbon Dioxide Exchange of Blue Grama Swards as Influenced by Several Ecological Variables in the Field." J. Appl. Ecol. 14:205-213.

Caldwell, M. M. 1970. "The Effect of Wind on Stomatal Aperature, Photosynthesis, and Transpiration of Bhododendron ferrigineum L. and Binus cembra L." Centralblatt fur das Gesamt Fortwesen 87:193-201.

Caldwell, M. C., T. J. Dean, R. S. Nowak, R. S. Dzurec, and J. H. Richards. 1983. "Bunchgrass Architecture, Light Interception, and Water Use Efficiency: Assessment by Fiber Optic Point Quadrats and Gas Exchange." Oecologia 59:178-184.

Campbell, G.S., and G. A.Harris. 1977. "Water Relations and Water Use Patterns for Artemisia tridentata Nutt. in Wet and Dry Years." Ecology 58:652-660.

Cowan, I. R. 1977. "Stomatal Behavior and Environment." Advances in Botanical Besearch 4:117-228.

Daubenmire, R. 1959. "Canopy Coverage Method of Vegetation Analysis." Northwest Sci. 33:43-64.

Daubenmire, R. 1970. Steppe Vegetation of Washington. Agricultural Exp. Sta. Technical Bulletin No. 62, Washington State University, Pullman, Washington.

Farquhar, G. D. 1978. "Feedforward Responses of Stomata to Humidity." Australian J. Plant Physiol. 5:787-800.

Farquhar, G. D., and T. D. Sharkey. 1982. "Stomatal Conductance and Photosynthesis." Ann. Rev. Plant Physiol 33:317-345. 
Fayer, M. J., G. W. Gee, and T. L. Jones. 1986. UNSAT-H Version 1.0: Unsaturated Flow Code Documentation and Applications for the Hanford Site. PNL-5899, Pacific Northwest Laboratory, Richland, Washington.

Hanks, R.J., and G. L. Ashcroft. 1980. "Applied Soil Physics." In Advanced Series in Agricultural Sciences, Vol. 8. Springer-Verlag, Berlin.

Hsiao, T. C. 1975. "Variables Affecting Stomatal Opening - Complicating Effects." In Measurement of Stomatal Aperature and Diffusive Resistance. ed., E. T. Kanemasu. College of Agricultural Research Center Bulletin No. 809, Washington State University, Pullman, Washington.

Jarvis, P. G., and K. G. McNaughton. 1986. "Stomatal Control of Transpiration: Scaling Up from Leaf to Region." Adv, in Ecol. Res. 15:1-49.

Koide, R. T., L. F. Huenneke, and H. A. Mooney. 1987. "Gopher Mound Soil Reduces Growth and Affects Ion Uptake of Two Annual Grassland Species." Decologia 72:284290.

Kramer, P. J. 1983. Water Relations of Plants. Academic Press. New York.

Kuppers, M., and E. D. Schulze. 1985. "An Empirical Model of Net Photosynthesis and Leaf Conductance for the Simulation of Diurnal Courses of $\mathrm{CO}_{2}$ and $\mathrm{H}_{2} \mathrm{O}$ Exchange." Australian J. Plant Physiol, 12:513-526.

Lange, O. L., R. Losch, E-D Schulze, and L. Kappen. 1971. "Responses of Stomata to Changes in Humidity." Planta 100:76-86.

Louwerse, W., and J. W. Eikhoudt. 1975. "A Mobile Laboratory for Measuring Photosynthesis and Transpiration of Field Crops." Photosynthetica 9:31-34.

Mansfield, T. A., A. R. Wellburn, and T. J. S. Moreira. 1978. "The Role of Abscisic Acid and Farnesol in the Alleviation of Water Stress." Philos. Trans. B. Soc. Lendon. Ser. B 284:471-482.

McKinion, J. M., and H. F. Hodges. 1985. "Automated System for Measurement of Evapotranspiration from Closed Environmental Growth Chambers." Transactions ASAE 28:1825-1828.

Meidner, H., and T. A. Mansfield 1968. Physiology of Stomata. McGraw-Hill, London.

Peterson, G.A., T. L. Loudon, and G. E. Merva. 1985. "A Comparison of ET Measured by Portable Chamber with Lysimeter Data." In Advances in Evapotranspiration: Proceedings of the National Conference on Advances in Evapotranspiration. ASAE. Pub. 14-85, American Society of Agricultural Engineers, St. Joseph, Michigan.

Raschke, L. 1975. "Stomatal Action." Ann. Rev. PlantPhysiol, 26:309-340. 
Raschke, L. 1979. "Movements of Stomata." In Physiology of Movements.

Encyciopedia of Plant Physiology New Series, Vol. 7, pp. 383-441, eds., W. Haupt, and M. E. Feinleib., Springer-Verlag, Berlin.

Redmann, R. E. 1978. "Seasonal Dynamics of Carbon Dioxide Exchange in a Mixed Grassland Ecosystem." Can.J.Bot. 56:1999-2005.

Reicosky, D. C., B. S. Sharratt, J. E. Ljungskull, and D. G. Baker. 1981. "Comparison of Alfalfa Evapotranspiration Measured by a Weighing Lysimeter and a Portable Chamber." Agric. Meteorol. 28:205-211.

Reynolds, J. F., and B. Acock. 1985. "Predicting the Response of Plants to Increasing Carbon Dioxide: A Critique of Plant Growth Models." Ecol_. Model. 29:107-129.

Reynolds, J. F., R. L. Dougherty, J. D. Tenhunen, and P. C. Harley. 1988. "PRECO: A Model for the Simulation of Plant Response to Elevated $\mathrm{CO}_{2}$." In Response of Vegetation to Carbon Dioxide, No. 042. U. S. Department of Energy, Carbon Dioxide Research Division, Washington, DC, and Systems Ecology Research Group, San Diego State University, San Diego, California.

Roessler, P. G., and R. K. Monson. 1985. "Midday Depression in Net Photosynthesis and Stomatal Conductance in Yucca glauca. "Oecologia 67:380-387.

Schulze, E.-D. 1983. "Photosynthetic $\mathrm{CO}_{2}$ Uptake and Whole Plant Growth as Related to Plant Water Relations." Ber. Deutsch. Bot. Ges. Bd. 96:391-402.

Sharkey, T. D., and K. Raschke. 1980. "Effects of Phaseic Acid and Dihydrophaseic Acid on Stomata and the Photosynthetic Apparatus." Plant Phvsiol. 65:291-297.

Sheriff, D. W. 1979. "Stomatal Aperature and the Sensing of the Environment by Guard Cells." Plant. Cell, and Environ, 2:15-22.

Tazaki, T., K. Ishihara, and T. Usijima. 1980. "Influence of Water Stress on the Photosynthesis and Productivity of Plants in Humid Areas." In Adaptation of Plants to Water and High Temperature Stress, eds., N. C. Turner, and P. J. Kramer, pp. 309-321, John Wiley \& Sons, New York.

Thorniey, J. H. M. 1976. Mathematical Models in Plant Physiology. Academic Press, London.

Tranquillini, W., and M. C. Caldwell. 1972. "Integrated Calibrations of Plant Gas Exchange Systems." Ecology 53:974-976.

Turner, N. C., and P. J. Kramer. 1980. Adaptation of Plants to Water and High Temperature Stress. John Wiley \& Sons, New York.

U.S. Department of Energy (DOE). 1987. Final Environmental Impact Statement. Disposal of Hanford Defense High-Level Transuranic and Tank Waste. DOE/EIS0113, U.S. Department of Energy, Washington, DC. 
Warrit, B., L. L. Landsberg, and M. R. Thorpe. 1980. "Responses of Apple Leaf Stomata to Environmental Factors." Plant. Cell, and Environ. 3:13-22.

Waugh, W. J. and Link, S. O. 1988. Barrier Erosion Control Test Plan: Gravel Mulch. Vegetation and Soil Water Interactions. WHC-EP-0067, Westinghouse Hanford Company, Richland, Washington.

Wing, N. R. 1988. Protective Barrier and Warnino Marker System Development Plan. WHC-EP-0169, Westinghouse Hanford Company, Richland, Washington. 


\section{DISTRIBUTION}

No. of

Copies

OFFSITE

2 DOE Otfice of Scientific and

Technical Information

W. J. Waugh

UNC Geotech

DOE-ID GJPO

P.O. Box 1400

Grand Junction, CO 81502

\section{ONSITE}

9 DOE Richland Operations Office
G. J. Bracken
J. J. Broderick
P. K. Clark
R. D. Freeburg
R. E. Gerton
R. D. lzatt
S. M. Prestwich
G. W. Rosenwald
J. P. Sands

27 Westinghouse Hanford Company
M. R Adams
L. C. Brown
J. W. Cammann
R. A. Carlson
H. F. Daugherty
K. A. Gasper
W. F. Heine
J. M. Henderson
G. W. Jackson
K. N. Jordan
D. S. Landeen
R. E. Lerch
H. E. McGuire
K. W. Owens

No. of

Copies

P. C. Payne

K. L. Petersen

S. J. Phillips

J. F. Relyea

$R$ C. Roos

R. C. Routson

W. W. Schulz

D. A. Turner

S. A. Weigman

N. R Wing

D. D. Wodrich

R. D. Wojtasek

D. E. Wood

36 Pacific Northwest Laboratory

L. L. Cadwell

M. D. Campbell

L. E. Eberhardt

J. W. Falco

M. J. Fayer

M. G. Foley

H. D. Freeman

G. W. Gee (2)

P. C. Hays

T. L. Jones

C. T. Kincaid

R R Kirkham

G. V. Last

M. W. Ligotke

S. O. Link (5)

G. P. O'Connor

L. E. Rogers

M. A. Simmons

R. L. Skaggs

T. L. Stewart

J. A. Stottlemyre

G. P. Streile

J. M. Thomas

R L. Treat

R. E. Wildung

Publishing Coordination

Technical Report Files (5) 
